\title{
PEMANFAATAN PROGRAM DESA BROADBAND TERPADU OLEH MASYARAKAT DESA LUTHARATO
}

\section{INTEGRATED BROADBAND VILLAGE PROGRAM UTILIZATION BY LUTHARATO VILLAGERS}

\author{
Darman Fauzan Dhahir \\ Balai Besar Pengembangan SDM dan Penelitian Kominfo Makassar \\ J1. Prof. Dr. Abdurrahman Basalamah II No.25, Makassar, 90231, Telp/Fax: 0411-4460084 \\ darm007@kominfo.go.id
}

Diterima : 17 Mei 2018

Direvisi : 28 Mei 2018

Disetujui : 02 Agustus 2018

\begin{abstract}
To achieve a more equitable distribution of wealth, the Indonesian Government has strived to open the communication access of the frontier, remote and outermost areas by establishing The Integrated Broadband Village Program. This is expected to raise their knowledge level and communication accesses. However, it is reported that many of such empowerment programs are mistargeted and fail to empower people. This study aims to confirm the report by providing an overview of community participation in receiving and utilizing the facilities in one of those villages, i.e. Lutharato, South Lamaknen subdistrict, East Nusa Tenggara. This research used qualitative descriptive approach. Data were collected from Pandu Desa, headman, users, communities, and territories and analysed using interactive model. It shows that although Pandu Desa are actively disseminating it, most locals have not yet adopted the technology. So far, the facility have predominantly been used by the migrants and the surrounding community, who are already familiar with the Internet. Although the utilization is not yet appropriate, the community welcomes the program and refuses to have the existing facilities withdrawn.
\end{abstract}

Keywords: Agent of Change, Development Communication, Diffusion of Innovation, Integrated Broadband Villages Program, Public Education

\begin{abstract}
ABSTRAK
Untuk mewujudkan pemerataan kesejahteraan masyarakat, Pemerintah Republik Indonesia (RI) berusaha membuka akses komunikasi masyarakat desa Terdepan, Tertinggal, Terluar (3T), salah satunya dengan program Desa Broadband Terpadu (DBT) yang diharapkan dapat meningkatkan akses komunikasi dan pengetahuan masyarakat. Akan tetapi, banyak laporan yang menyatakan bahwa banyak dari program pemberdayaan masyarakat semacam ini yang salah sasaran, sehingga gagal membuat masyarakat berdaya. Penelitian ini bertujuan untuk mengonfirmasi laporan tersebut dengan memberikan gambaran tentang partisipasi masyarakat dalam menerima dan memanfaatkan fasilitas DBT di salah satu DBT, yaitu Desa Lutharato, Kecamatan Lamaknen Selatan, Nusa Tenggara Timur (NTT). Penelitian ini menggunakan pendekatan kualitatif deskriptif. Analisis data dilakukan dengan menggunakan model interaktif. Data diperoleh dari Pandu Desa, Kepala Desa, pengguna, masyarakat sekitar, dan wilayah DBT. Hasilnya menunjukkan bahwa walaupun pengelola DBT aktif dalam menyosialisasikannya, kebanyakan masyarakat setempat belum memutuskan untuk mengadopsi teknologi tersebut. Sejauh ini, fasilitas tersebut lebih banyak digunakan oleh para pendatang dan masyarakat sekitar yang telah terbiasa menggunakan internet. Walaupun pemanfaatannya belum sesuai, masyarakat menyambut gembira program tersebut dan tidak ingin apabila fasilitas yang ada ditarik.
\end{abstract}

Kata Kunci: Agen Perubahan, Desa Broadband Terpadu, Difusi Inovasi, Edukasi Masyarakat, Komunikasi Pembangunan 


\section{PENDAHULUAN}

Indonesia masih memiliki desa 3T. Karakter desa yang minim sarana komunikasi dan informasi tersebut menjadi salah satu alasan mengapa masyarakatnya tidak mengakses informasi secara luas, sekaligus tidak terakses, sehingga literasi mereka, termasuk dalam hal pengetahuan untuk mengoptimalkan potensi lokal yang ada, lebih rendah dibandingkan wilayah kota (Tahir, 2013). Akses rendah tersebut juga meminimalisasi peluang kerja sama dengan pelaku-pelaku ekonomi dalam cakupan wilayah yang lebih luas (Syahza, 2013).

Kesenjangan digital memang tidak hanya terjadi di Indonesia (Wang, Bennett, \& Probst, 2011), namun hal tersebut tidak dibiarkan oleh pemerintah. Salah satu bukti upaya Pemerintah RI membuka akses komunikasi masyarakat desa 3T, adalah membuat program Desa Broadband Terpadu (DBT), yaitu penyediaan perangkat dan akses internet pada 50 desa pada tahap pertama di tahun 2015, dan terus bertambah dengan target 1600 desa hingga tahap kelima di tahun 2018 (Hamjen, 2016). Program DBT bertujuan untuk mendukung kegiatan mayarakat desa setempat sesuai dengan karakteristik masing-masing, baik desa nelayan, desa pertanian, maupun desa pedalaman (Kementerian Komunikasi dan Informatika, 2015). Diharapkan, berawal dari tersedianya sarana telekomunikasi di desadesa tersebut, masyarakat akan mengetahui manfaatnya (Wahyuningsih \& Kusumawati, 2015). Setelah itu, masyarakat akan memanfaatkannya sehingga akses komunikasi dan informasi dari dan menuju desa-desa 3T akan terbuka, dan akhirnya masyarakat desa merasakan kesejahteraan, sebab kualitas dan daya saing sumber daya manusia (SDM) serta perekonomian mereka meningkat, dan pembangunan berjalan (Hariyanti, 2017). Penyediaan fasilitas fisik memang dipercaya sebagai salah satu cara untuk menstimulasi pengembangan SDM (Widjajanti, 2011). Program serupa telah dilakukan oleh beberapa negara dan menunjukkan hasil yang positif (Heydari, 2015; Mathur \& Ambani, 2005; Tahir, Malek, \& Ibrahim, 2016).

Program pemberdayaan semacam ini akan berhasil jika masyarakat penerimanya aktif berpartisipasi secara kolektif, sebagaimana yang dialami oleh masyarakat Kabupaten Badung. Menurut mereka, bantuan yang diberikan kepada mereka telah memenuhi lima prinsip dasar pembangunan, yaitu pro-poor, pro-growth, pro-job, procultural, dan pro-environment (Suartha, 2012). Sayangnya, selain yang berhasil, masih banyak desa yang mengalami kegagalan. Firmansyah (2012) yang meneliti Program PNPM Mandiri Pedesaan, menyimpulkan bahwa program tersebut belum mampu memberdayakan masyarakat sasarannya. Dia menyatakan bahwa program pemberdayaan dengan tujuan untuk mewujudkan mentalitas self-help justru menghasilkan mentalitas helpme. Selain itu, Muslim (2015) mengungkapkan bahwa fasilitas internet yang disediakan sebagai alat perolehan informasi bagi masyarakat Desa Cihideung yang kebanyakan berprofesi sebagai petani tanaman hias, ternyata tidak dimanfaatkan secara optimal. Masyarakat setempat lebih memilih untuk memenuhi kebutuhan informasi dengan komunikasi secara langsung, interpersonal, dengan sumbersumber informasi yang bersifat personal dan bukan dari yang termediasi internet.

Kurangnya partisipasi masyarakat dalam memanfaatkannya juga terasa pada 
Program DBT. Buktinya, setelah DBT direalisasikan, Usman (2016) melaporkan bahwa elemen pemerintah masih menjadi yang paling dominan dalam pengelolaan DBT di Jawa Tengah dan Yogyakarta, walaupun mereka mengaku bahwa masyarakat diberi porsi untuk berperan dalam pengembangan DBT melalui tiga mekanisme, yakni: pemberdayaan seluruh elemen masyarakat, pengarahan dan dukungan dalam hal kelembagaan, infrastruktur, SDM, kesiapan sosial, dan tata kelola internet, serta konten. Di tempat lain, salah satu desa yang memiliki prestasi dalam pemanfaatan TIK, yaitu Desa Cikadu, yang merupakan salah satu DBT yang menerima penghargaan Destika (Desa Teknologi Informasi Komunikasi) pada tahun 2014 dan program Desa Emas (Enterpreneur, Mandiri, Adil dan Sejahtera) di Jawa Barat pada tahun 2017, mencapai keberhasilannya berkat peran besar para relawan TIK, bukan karena partisipasi masyarakat setempat. Ini berarti relawan TIK tidak berhasil mendampingi masyarakat (Hariyanti, 2017). Ginting (2017) juga menemukan hal yang sama dalam implementasi DBT di Provinsi Riau, yakni para Pandu Desa belum mampu menjadi jembatan antara fasilitas TIK yang disediakan dan masyarakat desa. Temuantemuan tersebut diperkuat oleh Amin (2017) yang menyimpulkan bahwa DBT di wilayah Papua dan NTT memiliki risiko paling tinggi pada aspek SDM. Di sisi lain, sarana DBT yang telah diterima oleh desa-desa tersebut ternyata umumnya masih berfungsi (Amin, 2017) dan masih dimanfaatkan (BBPPKI Makassar, 2016). Berdasarkan temuan para peneliti tersebut, tampak bahwa pemanfaatan DBT masih belum sejalan dengan perencanaannya. Dengan demikian, harapan bahwa DBT akan membawa masyarakat desa menuju arah kesejahteraan berisiko gagal tercapai.

Penerimaan dan pemanfaatan masyarakat terhadap keberadaan DBT dapat ditinjau dengan merujuk pada model penelitian yang diajukan oleh Rogers (1986). Ia berfokus pada empat hal, yaitu: karakter individu (sosial-ekonomi, kebiasaan komunikasi, sikap, dan keterampilan), adopsi teknologi (adopter vs rejector dan level inovasi), pemanfaatan teknologi (frekuensi dan variasi), dan dampak sosial (produktivitas, kaya informasi vs miskin informasi). Sebelumnya, Rogers (1973) telah mengajukan konsep difusi inovasi dalam bidang pertanian yang dipahami oleh Cangara (2015) bahwa pengenalan suatu inovasi ditentukan oleh tiga tahap, yaitu: tahap awal, tahap proses dan tahap konsekuensi. Karakter individu dari khalayak adalah hal dominan yang memengaruhi tahap awal. Tahap proses terdiri atas pengetahuan, pertimbangan dan keputusan. Pengetahuan terhadap sistem sosial akan memotivasi khalayak untuk melanjutkan ke proses selanjutnya jika inovasi yang dianggap sebagai barang baru, selaras dengan sistem sosial yang dianut. Setelah itu, akan terjadi proses pertimbangan, yaitu ketika khalayak mulai mempertanyakan manfaat apa yang bisa diperoleh dengan mengadopsi inovasi tersebut, apakah compatible, tidak rumit, dapat diuji coba dan observable. Setelah mempertimbangkan, barulah khalayak akan mengambil keputusan untuk megadopsi inovasi atau menolaknya. Pada tahap konsekuensi, pengadopsi inovasi akan terbagi ke dalam tiga perilaku, yaitu: melanjutkan adopsi dan mengganti dengan alat serupa namun dengan manfaat yang sama 
jika harapan sesuai dengan kenyataan atau kenyataan lebih baik, serta berhenti melakukan adopsi jika harapannya terhadap inovasi tersebut tidak tercapai. Sementara itu, para penolak inovasi, kemungkinan akan tetap menolak jika melihat para pengadopsi gagal mencapai standar manfaat versi para penolak, kecuali jika yang terjadi adalah sebaliknya, maka kemungkinan mereka akan mengadopsinya.

Dalam tahap-tahap adopsi inovasi, diperlukan peran agen untuk menyukseskan inovasi yang ditawarkan (Derzon \& Lipsey, 2002; Suprapto, 2009; Whitehead, 1959). Sebenarnya, para agen memiliki suatu kelebihan, yaitu mengetahui karakter penduduk setempat, sebab mereka sendiri adalah orang lokal, sebagaimana yang diungkapkan oleh Hariyanti (2017). Berbicara dengan bahasa yang sama dengan khalayak tentu akan mendukung terwujudnya komunikasi yang efektif (Nan, Zmud, \& Yetgin, 2013).

Pada program DBT, salah satu yang dianggap sebagai agen inovasi adalah pengelola DBT di tingkat desa. Sejatinya, tugas mereka adalah sebagai jembatan antara inovator dan masyarakat. Keefektifan mereka berkomunikasi dengan masyarakatlah yang memengaruhi keberhasilan program tersebut. Mereka diberi tanggung jawab untuk mentransfer pengetahuan dengan berbagai teknik yang sesuai, sehingga khalayak tergiring mendukung sesuatu yang ditawarkan dan akhirnya mengubah perilaku. Perubahan perilaku yang diharapkan adalah dari yang semula tidak memanfaatkan TIK, menjadi memanfaatkan TIK untuk mengembangkan kapasitas SDM dan ekonomi.

Fasilitas internet seperti DBT bisa dimanfaatkan untuk promosi produk lokal, misalnya pariwisata (Zhou, 2014), pertanian, kehutanan, perikanan (Soekartawi, 2007), dan produk lain. Selain itu, DBT juga bisa digunakan sebagai sarana memperoleh informasi dan ilmu pengetahuan $(\mathrm{Lu}, \mathrm{Xu}, \&$ Wallace, 2018), hiburan (Muslim, 2015), bersosialisasi (Abraham, 2014), dan lain-lain.

\section{METODOLOGI PENELITIAN}

Penelitian ini dilakukan untuk mengonfirmasi partisipasi masyarakat dalam menerima dan memanfaatkan fasilitas DBT, dengan cara mengungkap profil pengguna fasilitas DBT, hal-hal yang mereka lakukan, dan motivasi mereka dalam menggunakan fasilitas tersebut. Penelitian ini juga akan dilengkapi dengan deskripsi kegiatan sosialisasi (jika ada) yang dilakukan oleh pengelola DBT, yang merupakan agen inovasi. Selain itu, akan digambarkan persepsi masyarakat sekitar terhadap keberadaan fasilitas DBT. Oleh karena penelitian ini berusaha untuk menggambarkan kehidupan sosial, maka metode yang digunakan adalah kualitatif deskriptif.

Data penelitian dikumpulkan dengan teknik wawancara dan observasi. Dua teknik tersebut dilakukan secara tidak teratur. Ada kalanya, keduanya dilakukan secara bersamaan, tetapi ada kalanya pula salah satu teknik dilakukan lebih dahulu dibandingkan yang lainnya. Informan terdiri atas Pandu Desa, Kepala Desa, pengguna, dan masyarakat sekitar DBT. Sementara itu, observasi dilakukan pada wilayah desa, aktivitas masyarakat, fasilitas DBT, pengguna, dan Pandu Desa. Data umumnya diperoleh dari kegiatan pengumpulan data yang dilakukan pada tahun 2016, namun dilengkapi dengan beberapa pemutakhiran 
data secara online yang dilakukan hingga awal tahun 2018.

Data yang diperoleh akan dianalisis dengan menggunakan model interaktif Miles dan Huberman yang terdiri dari reduksi dan penyajian data, serta simpulan. Kesimpulan diambil setelah melewati tahap-tahap pembacaan dan perenungan, eksplorasi, melihat kode dan hubungan, serta meninjau dan menyempurnakan data (Bazeley, 2013).

Definisi DBT dalam penelitian ini adalah perangkat dan akses internet yang telah disediakan oleh Kementerian Komunikasi dan Informatika RI pada salah satu dari 50 desa 3T di tahun 2015, yaitu Desa Lutharato. Desa tersebut dipilih untuk diteliti karena termasuk DBT yang memiliki risiko kegagalan paling rendah dan direkomendasikan agar model pengelolaannya direplikasi di tempat lain (Amin, 2017; BBPPKI Makassar, 2016).

Pemanfaatan memiliki dua makna dalam penelitian ini. Pertama, proses atau cara fasilitas DBT digunakan. Dalam hal ini, akan digambarkan hal-hal yang diakses dan diunggah, serta pihak-pihak yang berinteraksi dengan pengguna DBT. Kedua, harapan yang ingin dicapai dari penggunaan teknologi tersebut. Sementara itu, Pandu Desa adalah pihak yang disebut sebagai pengelola DBT. Cara mereka memasyarakatkan Program DBT dan memandu para pengguna DBT akan diuraikan.

\section{HASIL DAN PEMBAHASAN}

Desa Lutharato adalah desa yang berbatasan dengan wilayah Timor Leste dan terletak $50 \mathrm{~km}$ dari pusat Kabupaten Belu, NTT. Sebagian infrastruktur jalan menuju desa tersebut masih sangat buruk. Dengan kendaraan roda dua, jalan utama sejauh $40 \mathrm{~km}$ yang merupakan tanjakan, turunan dan dataran yang sudah diaspal dapat ditempuh dalam waktu 60 menit. Sementara itu, untuk menempuh $10 \mathrm{~km}$ sisanya yang masih berupa tanah berbatu yang penuh semak, diperlukan 40 menit untuk sampai ke lokasi fasilitas DBT. Desa yang termasuk kategori rural ini belum terjangkau fasilitas broadband dari perusahaan-perusahaan telekomunikasi yang beroperasi di Indonesia. Meskipun sesekali ada sinyal yang muncul dan terlihat pada sensor indikator pada ponsel, bila sinyal tersebut digunakan, maka pengguna akan terbebani dengan biaya roaming. Hal ini merupakan problematika klasik yang masih terus terjadi di daerah 3T (Rachbini, 2002; Saleh \& Hadiyat, 2016; Yusuf, 2015). Sinyal siaran televisi dan radio analog hanya menjangkau sebagian kecil wilayah desa, itu pun dengan sinyal yang lemah. Untungnya, Desa Lutharato sudah terjangkau fasilitas listrik dari PT. PLN sehingga mereka telah menggunakan alat listrik untuk penerangan. Kondisi tersebut sejalan dengan kondisi masyarakat yang mayoritas tidak memiliki fasilitas komunikasi dan informasi elektronik, seperti ponsel, radio dan televisi.

Masyarakat Desa Lutharato cenderung pemalu. Mereka memilih tidak menegur orang asing yang beraktivitas di wilayah mereka. Kebanyakan mereka berprofesi di bidang pertanian (termasuk peternakan). Mereka bercocok tanam di lereng-lereng bukit. Sebagian dari hasil pertanian mereka yang berupa sayur, buah-buahan, ikan lele, babi dan sapi dikonsumsi sendiri, sebagian lainnya dijual ke daerah-daerah sekitar, terutama di wilayah urban. Para pedagang dari kota datang untuk membeli hasil 
pertanian tersebut, kemudian mendistribusikannya di kota.

Selain bertani, sebagian masyarakat, terutama kaum wanita, berprofesi sebagai pengrajin tenun ikat khas masyarakat Belu. Potensi lain yang dapat dijumpai di Lutharato adalah tanaman kapas yang merupakan bahan utama kain, tithonia diversifolia yang berkhasiat untuk menurunkan gula darah (Miura, Nosaka, Ishii, \& Ishida, 2005), serta Lantana dan Gandarusa yang keduanya memiliki manfaat sebagai zat antiinflamasi (Hidayati, Listyawati, \& Setyawan, 2008; Laksmitawati et al., 2016).

Kondisi Desa Lutharato tersebut menjadi alasan yang tepat untuk menjadikannya penerima Program DBT. Setidaknya, walaupun infrastruktur jalan kurang memadai, masyarakatnya tidak menjadi 'kura-kura dalam tempurung' akibat terkungkung dalam desa yang minim fasilitas komunikasi dan informasi. Dengan adanya fasilitas tersebut, masyarakat diharapkan bertambah pengetahuannya, terutama dalam mengenali potensi SDM dan sumber daya alam (SDA) yang dimiliki. Selain itu, mereka juga dapat berkomunikasi dan mempromosikan potensi-potensi ekonomi yang mereka miliki kepada masyarakat yang lebih luas dengan harga yang lebih menguntungkan.

Fasilitas DBT mulai beroperasi di Desa Lutharato sejak semester II tahun 2015. Fasilitas tersebut terdiri atas lima set komputer online berbasis satelit dan sebuah televisi layar datar berukuran 42 inci yang ditempatkan di sebuah ruangan terpisah dekat Balai Desa dan Pos Kesehatan Desa. Sebelumnya, ruangan tersebut merupakan salah satu ruang kelas Pendidikan Anak Usia Dini. Pada saat observasi, diperlukan waktu sekitar dua menit untuk memuat halaman login Facebook dan lima menit untuk pemutaran video berdurasi dua menit di Youtube.

Fasilitas DBT Lutharato dikelola oleh seorang Pandu Desa berpendidikan S1 Hukum. Dia merupakan penduduk asli setempat, bukan pendatang. Meskipun belum pernah diberi petunjuk teknis sosialisasi DBT, dia sangat giat memperkenalkan DBT kepada masyarakat. Sosialisasi dilakukannya di selasela acara adat, dan/atau kegiatan ibadah yang biasanya dihadiri oleh banyak warga Desa Lutharato. Dengan demikian, DBT diharapkan akan tersosialisasi dari mulut ke mulut. Bahkan sebenarnya, penempatan DBT pada lokasi tersebut juga merupakan salah satu upaya sosialisasi kepada masyarakat, sebab selain lokasi tersebut familier bagi mereka, hanya tempat itulah yang dianggap layak untuk menempatkan fasilitas DBT saat ini. Di samping itu, DBT juga disosialisasikan melalui penawaran kerja sama dengan sekolah-sekolah sekitar untuk menyelenggarakan pelatihan penggunaan internet.

Sayangnya, level pengenalan yang dilakukan baru bisa menembus difusi inovasi Tahap I dan separuh dari tahap II, yaitu tahap pengetahuan hingga pertimbangan. Berdasarkan penuturan para informan, selama ini Pandu Desa memang baru sebatas mengenalkan tentang keberadaan DBT, cara menggunakan browser, media sosial (Facebook dan Youtube), email, dan mesin pencari. Sebagian besar informan dari kalangan masyarakat Desa Lutharato (40 orang) mampu menunjukkan lokasi fasilitas DBT, namun pada saat pengumpulan data hanya lima dari mereka yang menyatakan pernah datang untuk menggunakan fasilitas 
tersebut. Masyarakat yang tidak menggunakan DBT mengaku bahwa mereka merasa belum memiliki alasan yang tepat untuk memanfaatkan fasilitas tersebut. Mereka menyatakan tidak tahu apa yang akan mereka lakukan di sana. Selain itu, mereka khawatir fasilitas tersebut akan rusak di tangan mereka, sebab mereka menganggap diri mereka tidak mengerti apa-apa tentang teknologi. Mereka belum paham tentang apa sebenarnya manfaat dari DBT. Ketika diberitahu bahwa keberdayaan SDM dan ekonomi mereka bisa meningkat melalui DBT, mereka masih sulit untuk percaya, dan bingung bagaimana bisa hal itu terjadi. Menurut mereka, untuk menjadi lebih sukses, maka seseorang harus bekerja keras dan tidak malas.

Anehnya, ketika ditanya persepsi tentang DBT, semuanya menganggapnya positif. Mereka bangga akan adanya fasilitas canggih di desa mereka. Meskipun masih terdapat beberapa kekurangan, mereka mengaku merasa diperhatikan oleh pemerintah dengan adanya program tersebut. Ketika ditanyakan pendapat mereka bilamana fasilitas tersebut ditarik atau dipindahkan ke desa lain, mereka tidak setuju.

Tidak semua yang menggunakan fasilitas DBT mampu mengoperasikan komputer. Sebagian dari mereka datang ke fasilitas DBT hanya untuk menonton teman mereka yang mengakses internet, atau minta dibukakan situs-situs tertentu.

Walaupun ada pengguna lokal, namun Pandu Desa mengakui bahwa mayoritas pengguna fasilitas DBT di Desa Lutharato bukan berasal dari desa tersebut. Profil para pengguna fasilitas tersebut berbeda-beda. Dilihat dari pekerjaannya, mereka adalah para tentara penjaga perbatasan yang tidak sedang bertugas, guru SMK, tenaga kesehatan, mahasiswa KKN, pastor, pelajar, dan masyarakat biasa (tidak bekerja atau pekerjaannya tidak menentu). Pandu Desa sendiri termasuk sebagai salah satu pengguna fasilitas tersebut. Hal yang mereka akses berbeda-beda. Para tentara biasanya mengakses berbagai hal, mulai dari membaca berita, membuka media sosial, chatting, menonton video, hingga membaca dan mengirim email. Guru SMK biasanya mengakses hal-hal yang berkaitan dengan mata pelajaran yang dia ajarkan dan media sosial. Pastor memanfaatkan fasilitas tersebut untuk berkomunikasi dengan jaringannya terkait materi khotbah. Sementara itu, pengguna lainnya lebih banyak memanfaatkan untuk media sosial. Seorang pengguna lokal menyatakan rasa bahagianya karena dengan fasilitas tersebut dia bisa melakukan kontak dengan saudara yang sedang studi di luar negeri setelah beberapa tahun kehilangan kontak. Pandu Desa juga ikut menggunakan fasilitas tersebut. Selain gemar mengakses media sosial, dia juga memanfaatkan fasilitas DBT untuk memperbarui informasi dan memasukkannya ke dalam aplikasi Sideka dan website dengan domain http://lutharato.desa.id/. Kedua aplikasi tersebut memang merupakan salah satu upaya mendorong kemandirian desa dan kawasan di Indonesia (Widyantara, Linawati, Mertasana, \& Setiawan, 2017). Website Desa Lutharato masih aktif dan dapat dikategorikan sebagai yang paling sering diperbarui, walaupun tidak semua menunya terisi. Hampir seluruh artikel yang ditampilkan adalah artikel berita. Hanya satu artikel yang merupakan promo produk, yaitu Minyak 
Rematik Togaku yang diakui terbuat dari dapur alam Lutharato. Sayangnya, produk tersebut belum ada yang terjual dari hasil promosi online. Hanya terdapat puluhan Facebook share atas beberapa artikel website tersebut, yang diawali oleh Pandu Desa, tanpa ada tanggapan dari pembaca. Hal tersebut menunjukkan minimnya pengunjung website.

Para pengguna DBT Lutharato tergolong aktif. Yang paling aktif di antara mereka adalah sang Pandu Desa sendiri. Hampir setiap hari, pada pukul 14.00 s.d 17.00 dan 19.00 s.d 22.00, dia berjaga di lokasi fasilitas DBT. Pengguna lain lebih aktif di waktu malam dibandingkan siang. Di siang hari, pengunjung hanya berkisar satu hingga dua orang, sementara pada malam hari berkisar antara lima hingga delapan orang.

Hampir semua pengguna yang diwawancarai mengaku sudah mengenal dan menggunakan internet, baik melalui ponsel maupun komputer, sebelum program DBT ada di Desa Lutharato. Hanya tujuh dari tiga puluh orang pengguna yang menyatakan baru mengenalnya, itu pun hanya tiga dari mereka yang sudah mampu mengoperasikan komputer, sementara selebihnya masih sekedar menonton atau mengikuti teman.

Dilihat dari profil para pengguna, fasilitas DBT Lutharato masih melenceng dari sasaran. Fasilitas tersebut adalah fasilitas untuk desa pertanian, namun tidak satu pun dari penggunanya yang berprofesi sebagai petani. Hal yang diakses pun lebih banyak yang bersifat hiburan, tidak berhubungan dengan pertanian atau pengenalan potensi SDM dan SDA Desa, kecuali sedikit upaya yang dilakukan oleh Pandu Desa, yaitu mempromosikan obat herbal lokal melalui media sosial dan website desa. Selain bertindak sebagai agen inovasi, Pandu Desa juga membimbing masyarakat untuk mengembangkan diri mereka melalui pemanfaatan fasilitas DBT. Hal ini sama dengan yang ditemukan di Desa Cikadu, yakni fakta bahwa yang aktif adalah Relawan TIK-nya, bukan masyarakatnya (Hariyanti, 2017).

Pengetahuan akan karakter masyarakat yang dimiliki oleh Pandu DBT Lutharato, sang agen inovasi yang berasal dari dalam lingkungan sendiri, ternyata tidak serta-merta menjadikan inovasi yang dia tawarkan diadopsi oleh masyarakat. Pandu Desa mengaku bahwa mereka pernah mengikuti pelatihan TIK, namun belum pernah mendapat pelatihan sosialisasi DBT. Menanggapi keadaan tersebut, pelatihan komunikasi bagi Pandu Desa bisa menjadi solusi. Dengan kelebihan yang mereka miliki dan kemampuan komunikasi yang lebih baik, kemungkinan keberhasilan sosialisasi akan lebih tinggi. Selain itu, para Pandu Desa belum membuat forum komunikasi online secara nasional sebagai wadah mereka untuk dapat berbagi pengalaman dan pengetahuan secara terus-menerus.

Masyarakat sudah terbiasa menjalani hidup tanpa TIK dan belum menyaksikan secara nyata manfaat TIK dalam mengembangkan keberdayaan SDM dan ekonomi. Mereka juga belum mengetahui cara menggunakan perangkat TIK yang disediakan. Hal-hal tersebut menjadi faktor penghambat adopsi inovasi ini.

Di sisi lain, keberadaan fasilitas DBT yang dibanggakan oleh mayoritas masyarakat, sebenarnya merupakan faktor pendukung adopsi inovasi, walaupun kebanggaan mereka baru sebatas karena telah memilikinya, bukan lantaran memanfaatkan atau merasakan manfaatnya. Akan tetapi, sekalipun fasilitas 
tersebut lebih banyak dinikmati oleh masyarakat luar Desa Lutharato, terjadi efek samping yang positif, yaitu para pendatang maupun masyarakat sekitar yang sejak awal sudah biasa terhubung dengan internet, menjadi terfasilitasi dan dapat berkomunikasi ketika berada di wilayah Desa Lutharato. Memang, penggunaan DBT belum menunjukkan tanda-tanda yang nyata mengarah kepada peningkatan kapasitas SDM dan ekonomi, namun setidaknya, fasilitas tersebut telah digunakan sesuai fungsi dasarnya, yaitu untuk berkomunikasi.

\section{KESIMPULAN DAN SARAN}

DBT Lutharato, salah satu Desa 3T, masih aktif dengan sarana yang masih berfungsi, namun yang berpartisipasi sebagai penggunanya bukanlah masyarakat sasaran sehingga target pemerintah untuk menyejahterakan masyarakat desa tersebut, yang diawali dengan penyediaan akses komunikasi dan informasi yang terbuka melalui Program DBT, belum tercapai. Masyarakat belum mau mengadopsi teknologi tersebut, padahal pengelola DBT telah dengan giat menyosialisasikanya kepada masyarakat setempat. Untungnya, fasilitas tersebut masih memiliki efek samping positif, yaitu digunakan oleh masyarakat dengan profil yang beragam untuk kepentingan dinas, pendidikan, komunikasi, dan terutama hiburan. Di sisi lain, warga desa merasa bangga dan diperhatikan oleh Pemerintah Pusat dengan terealisasinya program tersebut di desa mereka.

Walaupun tidak sesuai perencanaan awal, karena masih memiliki efek positif, disarankan agar fasilitas tersebut tetap dipertahankan. Adapun untuk mencari solusi atas tingkat adopsi masyarakat yang masih sangat rendah, pemerintah disarankan untuk melakukan penyusunan rencana komunikasi yang lengkap, dari riset hingga evaluasi dan perbaikan-perbaikan. Penelitian yang dapat dilakukan di masa akan datang antara lain mencakup potensi pelatihan komunikasi bagi Pandu Desa dalam keberhasilan sosialisasi DBT kepada masyarakat, dan tentang dampak penyampaian testimoni kepada masyarakat dari orang-orang yang telah sukses berkat pemanfaatan TIK. Dengan melihat bukti, setidaknya mereka bisa menjadi pengadopsi lambat, sebab dalam hal positif, lebih baik terlambat daripada tidak sama sekali.

\section{UCAPAN TERIMA KASIH}

Penulis mengucapkan terima kasih kepada pemerintah maupun masyarakat Desa Lutharato, atas izin, sambutan, dan informasi yang diberikan dalam rangka melakukan penelitian ini, terutama kepada Alfons Karaen, sang Pandu Desa.

Penulis juga mengucapkan terima kasih kepada BBPSDMP Kominfo Makassar yang telah memfasilitasi pelaksanaan penelitian ini, kepada reviewer atas masukannya, serta pihak-pihak lain yang berkontribusi pada artikel ini.

\section{DAFTAR PUSTAKA}

Abraham, F. Z. (2014). Pemanfaatan Media Online Terhadap Interaksi Sosial Masyarakat. Jurnal Penelitian Pers Dan Komunikasi Pembangunan, 18(2), hal. 171-184. http://jurnalp2kp.id/index.php/ jp2kp/article/view/17

Amin, M. (2017). Risk Level Measurement of Integrated Broadband Village Program 
in Papua and East Nusa Tenggara Region (Pengukuran Tingkat Risiko Program Desa Broadband Terpadu di Wilayah Papua dan Nusa Tenggara Timur). Journal Pekommas, 2(2), hal. 135-142. http://doi.org/10.30818/jpkm. 2017.2020203

Bazeley, P. (2013). Qualitative Data Analysis: Practical Strategies. (J. Seaman, Ed.). Singapore: Sage.

BBPPKI Makassar. (2016). Pengelolaan Risiko Pengembangan Desa Broadband di Wilayah Kerja BBPPKI Makassar. Makassar.

Cangara, H. (2015). Edisi Revisi Perencanaan \& Strategi Komunikasi. Jakarta: PT. Rajagrafindo.

Derzon, J. H., \& Lipsey, M. W. (2002). A Meta-Analysis of the Effectiveness of Mass-Communication for Changing Substance-Use Knowledge, Attitudes, and Behavior. Mass Media and Drug Prevention: Classic and Contemporary Theories and Research, hal. 231258.Mahwah, NJ: Lawrence Earlbaum Associates.

Firmansyah, H. (2012). Tingkat Keberdayaan Masyarakat dalam Program Pemberdayaan Masyarakat di Kota Banjarmasin dan Kabupaten Tanah Laut. AGRIDES: Jurnal Agribisnis Perdesaan, 2(1), hal. 53-67. https://www.neliti.com/ publications/ 9264/tingkat-keberdayaan-masyarakatdalam-program-pemberdayaan masyarakat-di-kota-ban

Ginting, M. D. (2017). Implementasi Desa Broadband Terpadu (Studi pada Enam Desa Penerima Program Desa Broadband Terpadu di Daerah Perbatasan). Jurnal Penelitian
Komunikasi Dan Pembangunan, 18(1), hal. 19-30. http://doi.org/10.31346/ jpkp.v18i1.758

Hamjen, H. (2016). Analisis Efektivitas Perangkat pada Program Desa Broadband Terpadu [Analysis of Device Effectiveness in Integrated Broadband Village Program]. Buletin Pos dan Telekomunikasi, 14(2), hal. 95112.

http://doi.org/10.17933/bpostel.2016.14 0203

Hariyanti, P. (2017). Peran Relawan TIK Dalam Program Desa Broadband Terpadu Cikadu, Cianjur, Jawa Barat. Jurnal Komunikasi, 12(1), hal. 19-34. http://jurnal.uii.ac.id/jurnal-

komunikasi/article/view/9917

Heydari, S. V. (2015). The Role of ICT on Social Development in the Rural Regions: A Case Study in Meshkinshar. Journal of Studies of Socio-Cultural Development, 4(2), hal. 85-101. http://www.sid.ir/En/Journal/ViewPaper .aspx?ID=514711

Hidayati, N. A., Listyawati, S., \& Setyawan, A. D. (2008). Kandungan Kimia dan Uji Antiinflamasi Ekstrak Etanol Lantana Camara pada Tikus Putih (Rattus norvegicus) Jantan. Bioteknologi, 5(1), hal. 10-17. http://doi.org/10.13057/biotek/c050102 Kementerian Komunikasi dan Informatika. (2015). Desa Broadband Terpadu. diakses pada tanggal 28 Februari 2016 dari https://kominfo.go.id/index.php/ content

/detail/5432/Siaran+Pers+No.62-PIHKOMINFO-08-2015+tentang+Desa +Broadband+Terpadu/0/siaran_pers Laksmitawati, D. R., et. Al. (2016). Anti- 
Inflammatory Potential of Gandarusa (Gendarussa vulgaris Nees) and Soursoup (Annona muricata L) Extracts in LPS Stimulated-Macrophage Cell (RAW264.7). Journal of Natural Remedies, 16(2), hal. 73-81. http://doi.org/10.18311/jnr/2016/5367

Lu, T., Xu, Y. C., \& Wallace, S. (2018). Internet Usage and Patient's Trust in Physician During Diagnoses: A Knowledge Power Perspective. Journal of the Association for Information Science and Technology, 69(1), hal. 110-120.

http://doi.org/10.1002/asi.23920

Mathur, A., \& Ambani, D. (2005). ICT and Rural Societies: Opportunities for Growth.International Information and Library Review, 37(4), hal. 345-351. http://doi.org/10.1080/10572317.2005.1 0762692

Miura, T., Nosaka, K., Ishii, H., \& Ishida, T. (2005). Antidiabetic Effect of Nitobegiku, the Herb Tithonia diversifolia, in KK-Ay Diabetic Mice. Biological \&Pharmaceutical Bulletin, 28(11), hal. 2152-2154. http://doi.org/ $10.1248 /$ bpb.28.2152

Muslim, A. (2015). Pemanfaatan Telecenter Balai Informasi Masyarakat Oleh Petani Tanaman Hias (Kasus Desa Cihideung). Jurnal Perpustakaan Pertanian, 22(1), hal. 1-7. http://doi.org/10.21082/jpp. v22n1.2013.p1-7

Nan, N., Zmud, R., \& Yetgin, E. (2013). A Complex Adaptive Systems Perspective of Innovation Diffusion: An Integrated Theory and Validated Virtual Laboratory. Computational and Mathematical Organization Theory, 20
(1), hal. 52-88. http://doi.org/10.1007/ s10588-013-9159-9

Rachbini, D. J. (2002). Ekonomi politik: paradigma dan teori pilihan publik. Jakarta: Ghalia Indonesia. https://scholar.google.com/citations?use $\mathrm{r}=$ wjeW8ksAAAAJ\&hl=en\&oi=sra

Rogers, E. M. (1973). Communication Strategies for Agricultural Development. Washington: Academy for Educational Development.

Rogers, E. M. (1986). Communication Technology: The New Media in Society. New York: The Free Press.

Saleh, B., \& Hadiyat, Y. D. (2016). Use of Information Technology Among Performers Micro Small Medium Enterprises In The Border Area (Study In Belu, East Nusa Tenggara). Pekommas, 1(2), hal. 141-152. http://doi.org/10.30818/jpkm.2016.2010 204

Soekartawi, S. (2007). E-Agribisnis: Teori dan Aplikasinya. Seminar Nasional Aplikasi Teknologi Informasi (SNATI), hal. 19-25. Malang: Universitas Islam Indonesia.

http://www.jurnal.uii.ac.id/index.php/Sn ati/article/download/1760/1540

Suartha, N. (2012). Esensi Bantuan Pemerintah Kabupaten Badung Terhadap Keberdayaan Masyarakat. Piramida, 8(2), hal. 85-92. https://ojs.unud.ac.id/ index.php/piramida/article/view/7000

Suprapto, T. (2009). Pengantar Teori \& Manajemen Komunikasi. Yogyakarta: Media Pressindo.

Syahza, A. (2003). Paradigma Baru: Pemasaran Produk Pertanian Berbasis 
Agribisnis di Daerah Riau.Jurnal Pembangunan Pedesaan, 8(2), hal. 1-11 http://repository.unri.ac.id/jspui/handle/ $123456789 / 3006$

Tahir, H. (2013). 'Nouveau Information Poor'dalam Peradaban Gelombang Ketiga (Fenomena Masyarakat Miskin Informasi di Kawasan Timur Indonesia). Profetik: Jurnal Komunikasi, 6(1), hal. 93-101. http://ejournal.uin-suka.ac.id/ isoshum/profetik/article/view/1179

Tahir, Z., Malek, J. A., \& Ibrahim, M. A. (2016). Developing Smart ICT in Rural Communities in Malaysia through The Establishment of Telecenters. E-Bangi, 11(1), hal. 227-242. http://ejournals. ukm.my/ebangi/article/view/14453

Usman, S. (2016). Pengembangan Desa Broadband Terpadu. Jurnal Ilmu Komunikasi (JIK), 14(3), hal. 189-198. http://jurnal.upnyk.ac.id/index.php/kom unikasi/article/view/2130

Wahyuningsih, S., \& Kusumawati, D. (2015). Strategi Pencapaian Pelanggan Pitalebar Bergerak Di Daerah Perdesaan Tahun 2019. Buletin Pos Dan Telekomunikasi, 13(2), hal. 165-176. http://doi.org/10. 17933/ bpostel.2015.130205

Wang, J. Y., Bennett, K., \& Probst, J. (2011). Subdividing the Digital Divide:
Differences in Internet Access and Use Among Rural Residents with Medical Limitations. Journal of Medical Internet Research, 13(1), hal. 1-10. http://doi.org/10.2196/jmir.1534

Whitehead, A. N. (1959). The Aims of Education. Daedalus, 88(1), hal. 192205.

Widjajanti, K. (2011). Model Pemberdayaan Masyarakat. Jurnal Ekonomi Pembangunan, 12(1), hal. 15-27. http://doi.org/10.23917/jep.v12i1.202

Widyantara, I. M. O., Linawati, L., Mertasana, I. P. A., \& Setiawan, W. (2017). Penerapan Sistem Informasi Desa dan Kawasan di Kabupaten Klungkung. Buletin Udayana Mengabdi, hal. 144-149. https://ojs.unud.ac.id/ index.php/jum/article/view/36088

Yusuf, I. A. (2015). Radio di Kawasan Perbatasan Indonesia dalam Centering the Margin. Jurnal Ilmu Komunikasi, 12(2), hal 175-188. http://doi.org/10. 24002/ jik.v12i2.469

Zhou, L. (2014). Online Rural Destination Images: Tourism and Rurality. Journal of Destination Marketing \& Management, 3(4), 227-240. http://doi.org/10.1016/ j.jdmm.2014.03.002 